УДК 069:[339.1+338.45](091)"189/191"

DOI: $10.26565 / 2220-7929-2020-58-07$

\title{
Шандра Ірина Олександрівна
}

доктор історичних наук, доцент

Харківська державна академія культури Бурсацький узвіз, 4, 61057, Харків, Україна

Email: irina shandra@ukr.net ORCID: 0000-0002-9092-413X

\section{ТОРГОВО-ПРОМИСЛОВІ МУЗЕЇ ЯК ЗАСІБ ЗБІЛЬШЕННЯ ТОВАРООБІГУ: СВІТОВИЙ ТА ВІТЧИЗНЯНИЙ ДОСВІД (КІНЕЦЬ ХІХ - ПОЧАТОК ХХ СТ.)}

Наприкінці XIX - на початку XX cm. для пожвавлення експорту та збільшення товарообігу між краӥнами ділові кола вдаються до заснування спеціальних музейних установ - торгово-промислових музеїв, експортних музеїв або музеїв зразків. Дослідження процесу створення таких закладів, функиіонального призначення їхніх основних структурних компонентів $i$ головних напрямів діяльності стало можливим у результаті залучення значного масиву поточних $i$ аналітичних даних із періодичних видань початку XX cm., діловодних матеріалів представницьких об'єднань підприємців та урядовопідприємницьких організацій сприяння зовнішній торгівлі (Російська експортна палата, м. Санкт-Петербург; 3 '̈ззи гірничопромисловців Півдня Росії, м. Харків; Харківський біржовий комітет тощьо). Торговопромислові музеї в статті проаналізовано як один зі складників реалізації економічних завдань окремих груп підприємиів та держав у цілому. Підкреслюється, щуо изі установи сприяли пожвавленню товарообігу між країнами та обміну найновішими підходами й прийомами ведення зовнішньоторгових операцій (укладання й супровід комериійних угод, створення широкої інформаційної бази й надання довідкової інформачиї, підтримка контактів між виробниками й споживачами, особливості доставки товарів ци новинки їхнього пакування тощзо). У статті подано кілька варіантів класифікації експортно орієнтованих музейних установ: за місцем знаходження (на теренах країни виробництва, на теренах країни можливого експорту); за головним призначенням (експортні, іміджеві). У результаті порівняльного аналізу діяльності (C) Шандра I. O., 2020 
західноєвропейських експортних музеїв та музеїв зразків Російської імперії у дослідженні робиться висновок про суттєве відставання останньої у справі заснування інституційних форм сприяння зовнішній торгівлі, незначне кількісне поширення таких музеїв у імперії та недостатнє представлення в них експортованих товарів.

Ключові слова: торгово-промисловий музей, експортний музей, музей зразків, товарообіг.

Процеси трансформації діалектичних категорій «зміст - форма» одвічні: нові часи зумовлюють інші форми або наповнюють іншим змістом наявні. Час капіталістичної модернізації другої половини XIX - початку XX ст. дуже насичений на подібні зміни. Одним із прикладів нового значення здавна відомої форми $є$ створення торговопромислових музеїв, де класична для таких установ мета збереження експонатів була замінена на діаметрально протилежну - їхній збут. Діяльність цих експортних музеїв, за оцінками сучасників, була досить результативною, а в деяких випадках - вирішальною для збільшення товарообігу та завоювання нових ринків збуту. Цей сюжет вкотре підтверджує невичерпність і множинність наповнення дефініцій «зміст» i «форма», спонукає і в сучасних умовах шукати гармонійного поєднання економічних завдань із діяльністю закладів культури, прагнути успішної реалізації комплексної стратегії господарського та духовно-культурного розвитку нашої держави.

Наукове дослідження торгових музеїв у країнах Західної Європи співпадає з часом їхнього заснування і мало на меті суто практичні завдання - узагальнення наявного досвіту організації торговопромислових музеїв і співвіднесення їхньої діяльності із завданнями експорту (наприклад, висвітлення роботи найдавнішого в Європі Брюссельського комерційного музею (Le Musée Commercial)).

У 1886 р. побачила світ праця Ф. Губера, в якій проаналізовано виставкову діяльність у Німеччині та ії вплив на вивізну торгівлю (Huber 1886). Лідер світової торгівлі кінця XIX - початку XX ст. Велика Британія отримувала значні прибутки від своїх капіталів за кордоном, про що наводилися дані в науковій літературі, а як один із результативних методів покращення експортних операцій виділявся й експозиційномузейний (Steffen 1896).

Перша велика узагальнююча робота з цієї проблематики в російській історіографії була написана проф. I. I. Янжулом на замовлення міністерства фінансів Російської імперії і розкривала історію створення, 
структуру та головні форми роботи цих закладів у країнах Західної Європи («Торговые музеи, экспортные союзы и склады товарных образцов», 1897) (Ianzhul 1897). Завдання виявилося для автора не 3 легких, про що науковець зазначав так: «Установи ці зовсім не публічні, тим більше, що всі вони важко доступні для будь-якої допитливої особи» (пер. 3 рос.) ${ }^{1}$ (Ianzhul 1897, VII). I було що охороняти від стороннього ока, адже в європейських країнах експортні музеї належали до елементів зовнішньоекономічної політики й складників комерційної таємниці.

На початку XX ст. діяльність торгово-промислових музеїв стає все більш масштабною, про що свідчить значно активніше висвітлення їхньої роботи в комплексних дослідженнях і періодичних виданнях Російської імперії. Так, серед заходів сприяння експорту торговопромислові музеї виділені в аналітичній роботі В. Ю. Шимановського та К. С. Лейтеса, підготовленій за сприяння міністерства фінансів як матеріали для перегляду російсько-німецького торгового договору (Shimanovskii, Leites 1913).

У періодичних виданнях того часу містяться як узагальнюючі статті щодо європейського досвіду роботи торгово-промислових музеїв, так і поточна інформація з приводу заснування чи проектування подібних установ або їхніх структурних підрозділів (журнали «Экономист России», «Русский экспорт», «Промышленность и торговля», «Торговопромышленный Юг», «Вестник русско-американской торговой палаты» та ін.) (Nadezhdin 1911; Roshchin 1909). Важливу первинну інформацію щодо формування економічно орієнтованих музейних закладів знаходимо у діловодній документації представницьких об'єднань підприємців та урядово-підприємницьких структур сприяння експортно-торговим операціям, як-то: Російська експортна палата, 3'їзди гірничопромисловців Півдня Росії, Харківський біржовий комітет тощо (Otchet Khar'kovskogo birzhevogo komiteta; Otchet Rossiyskoi éksportnoi palaty; Trudy XXXIV s"ezda gornopromyshlennikov).

У сучасній вітчизняній історіографії проблема експортних музеїв якщо і згадується, то як один з елементів інших більш масштабних процесів. Спеціального висвітлення ця тема не набула. Для європейських авторів ця тематика залишається окремою науковою проблемою і подається з точки зору взаємодії комерційного й музейного світів (Abbo 1993). Досліджуючи прояви корпоративізму, одну зі своїх статей проф. Ф. Майєрс присвятив промисловим і комерційним музеям (Mairesse 2018).

${ }^{1}$ Тут і далі, якщо не вказано інше, всі переклади належать авторці статті. 
Як для українського, так і для західноєвропейського наукового світу залишається проблемою сам факт взаємодії комерційної і музейно-виставкової діяльності, адже за своїм визначенням музей - це некомерційна, неприбуткова установа, яка зберігає, вивчає та експонує матеріальні й нематеріальні надбання людства. Не всі торгово-промислові музеї кінця XIX - початку XX ст. потрапляють під таке визначення, a експортні - повністю суперечать йому. I все ж таки практики й теоретики експортної торгівлі того часу найчастіше для позначення таких виставкових закладів використовували поняття «музей». На основі комплексу джерел, наукової літератури досліджуваного періоду та розвідках сучасних західноєвропейських авторів у цій статті порушено проблему формування торгово-промислових музеїв як інструменту збільшення товарообігу між країнами. Для розв'язання цієї загальної мети виділимо кілька дослідницьких завдань, а саме: причини формування торгово-промислових музеїв, їхня сутність і основні напрями діяльності, робота іноземних експортних музеїв, формування експортноорієнтованих музейних установ у Російській імперії та на українських землях, класифікація торгово-промислових музеїв, доцільність самого поняття «музеї» та причини його використання для експортних виставок.

Кінець XIX ст. - це час стрімкого розширення світового ринку, запеклої конкурентної боротьби між експортерами, нарощування виробництва і пошуку нових ринків збуту. Усі ці реалії робили недостатніми традиційну тактику експортної торгівлі, вимагали нових більш комплексних методів і форм популяризації власних товарів. Ураховуючи все це, світові економічні лідери вдаються до постійного і масштабного інформаційного супроводу експортних товарів. Форми такого інформування були досить різноманітними, як-то: організація виставок і торгово-промислових музеїв, утримання відповідної торгової агентури за кордоном, упорядкування консульської справи тощо.

Із наведеного переліку важливе значення у справі збільшення товарообігу західноєвропейські держави надавали і облаштуванню спеціалізованих торгово-промислових музеїв (музеїв зразків або експортних музеїв). На кінець ХІХ ст. сформувалося два основних види музеїв зразків: 1) торгові музеї, які працювали у власній країні з метою популяризації своїх виробів та вивчення іноземних ринків; 2) торгові музеї, які діяли в іноземних країнах з метою ознайомлення закордонних споживачів із вітчизняними товарами. Джерелами їхнього фінансування виступали держава, приватні особи або їхні асоціації. Колекції товарів, представлені в таких музеях, зазвичай були двох видів: зразки вітчизняних виробів (для ознайомлення внутрішніх i закордонних 
споживачів); зразки закордонних товарів (для ознайомлення вітчизняних виробників з іноземним асортиментом, пакуванням товарів, способами їхньої доставки або зберігання).

\section{Експортні музеї іноземних держав.}

Перші торгові музеї в Європі виникають у 80-х pp. XIX ст. Найдавнішим і найбільш облаштованим торговим музеєм Європи вважається Брюссельський комерційний музей (Musẽe commercial, 1882 р. заснування (Ianzhul 1897, 30)), який знаходився в підпорядкуванні міністерства закордонних справ і тісно співпрацював із консульською службою (Nadezhdin 1911, 5). Його метою було ознайомлення бельгійських промисловців і комерсантів із перебігом торгових справ у іноземних державах, надання їм допомоги у взаємодії із закордонними виробниками й споживачами (Le Musée Commercial, 6). Колекції зразків поділялися на три великі категорії: зразки товарів вивозу, зразки товарів ввозу, а також зразки пакування та оформлення товарів. Довідкове бюро Брюссельського комерційного музею акумулювало всю необхідну інформацію щодо виставлених експонатів, їхньої доставки й пакування, митних і залізничних тарифів тощо.

За прикладом брюссельського у Відні 1886 р. був організований «Австрійський торговий музей» (Nadezhdin 1911, 6). За статутом його метою було сприяти торговим відносинам австрійської монархії 3 іноземними країнами. Це завдання мало бути досягнуто шляхом організації постійних виставок торгового характеру, утримання довідкового бюро 3 питань міжнародних вантажних перевезень, підтримки постійних контактів із торговими кореспондентами, торговопромисловими установами, вченими-економістами тощо. Австрійський музей видавав щотижневий журнал «Торговий музей» (Handelsmuseum), в якому публікувалися матеріали з питань світового економічного розвитку (Nadezhdin 1911, 6). Музей прагнув поширювати й прикладні знання шляхом організації наукових читань і повноцінних торгових курсів, які проводилися в різних регіонах країни.

Аналогічні торгові музеї діяли в Італії (торгові музеї у Венеції, Мілані й Турині), Швеції (Торговий музей у Стокгольмі), Японії (Імператорський торговий музей у Токіо) та інших країнах і виступали складниками державної торгівельної політики щодо завоювання закордонних ринків збуту та моніторингу умов конкурентної боротьби на світовому ринку (Roshchin 1909, 16; Éksportnye soiuzy za granitsei, 129-132).

У 80-х pp. XIX ст. виникає ще один вид музеїв - «експортні склади товарних зразків», які, крім функцій звичайних експортних музеїв, 
здійснювали ще й безпосередню торгівлю експонованими товарами. У німецькому Штутгарті діяв найбільш успішний і найбільш вдало організований експортний склад зразків. Він був створений 1882 p. у вигляді товариства, усім учасникам якого надавалася можливість експонувати свої вироби й формувати експозиції товарів (Huber 1886, $22,26,35)$. Штутгартський склад мав свої відділення (Гамбург, Бремен, Афіни) та власних торгових агентів. Крім основних своїх завдань, експортний склад здійснював фахову підготовку всіх бажаючих з «основ експортної справи». Діяльність цього складу зразків була напрочуд ефективною - кількість комерційних звернень за рік нараховувала понад 4,5 тис. (Shimanovskii, Leites 1913, 36-37), а тому саме він став прикладом для утворення експортних складів у Лейпцизі, Франкфурті, Амстердамі, Белграді, Філадельфії та інших містах світу.

Наприкінці 80-х pp. XIX ст. вже спостерігалася загальна для багатьох країн світу тенденція облаштування своїх торгових музеїв у країнах експорту. У 1889 р. було відкрито одразу кілька торгово-експортних представництв: бельгійський музей у Константинополі, австрійський - в Калькутті, італійський - у Буенос-Айресі, англійський - у Гамбурзі (Nadezhdin 1911, 7). У 90-х рр. ХІХ ст. японські та американські промислові кола відкрили цілу низку таких установ у різних країнах світу.

Облаштування й утримання торгово-промислових музеїв вимагало значних коштів, у зв'язку з чим розширення їхньої мережі зустрічало стриманий ентузіазмпромисловців. Протепрактиказовнішньоторговельних угод кінця XIX - початку XX ст. доводила практичну користь таких установ (Steffen 1896, 38). Наприклад, генеральний агент штату Вікторія (Австралія) запевняв, що після відкриття торгового музею експорт збільшився на 103 \% (Roshchin 1909, 16).

У цілому, представники європейських торгово-промислових кіл діяльність експортних музеїв вважали результативною - значна частина експортних операцій у другій половині XIX - на початку $\mathrm{XX}$ ст. організовувалася за посередництва саме цих музейних установ. У часи капіталістичного господарства та ринкових відносин торговопромислові музеї в першу чергу були підпорядковані комерційній меті: сприяти збуту товарів власного виробництва та розширювати торгові зв'язки із закордонними партнерами.

\section{Експортні представництва Російської імперії за кордоном.}

Головною метою європейських музеїв зразків було дати можливість закордонним покупцям із мінімальними втратами часу ознайомитися 3 придатними для експорту товарами, цінами на них, 
умовами виробництва, оплати й доставки, тобто сприяти зближенню вітчизняних виробників з іноземними покупцями. У Російській імперії справа облаштування таких закладів розпочалася значно пізніше, ніж у Європі - тільки наприкінці XIX - на початку XX ст. зустрічаємо спроби організації експортних музеїв.

У 1889 р. російський уряд організував у Бухаресті (Румунія) постійну виставку-склад російських товарів, куди фабриканти й торговці могли звертатися з різноманітними запитами та відправляти зразки своїх товарів (Otchet Khar'kovskogo birzhevogo komiteta, IV). В Осаці (Японія) у 1890 р. була облаштована постійна виставка зразків місцевих й експортованих товарів із метою сприяння розвитку зовнішньоторгових відносин Японії з іноземними державами, у тому числі і з Російською імперією (Otchet Khar'kovskogo birzhevogo komiteta, IV).

У 1910 р. для пожвавлення торгових відносин між країнами був відкритий Російсько-Китайський торгово-промисловий музей в Харбіні. Цей заклад складався з таких підрозділів: 1) постійна виставка зразків російських i китайських товарів i сировини, які могли слугувати предметами товарообміну; 2) довідкове й посередницьке бюро; 3) «випробувальна станція для дослідження природи й властивостей продуктів і виробів» (Russko-Kitayskii torgovo-promyshlennyi muzei, 638).

На початку XX ст. розроблялися проекти створення російських експортних музеїв у Софії (Болгарія) та Тегерані (Османська імперія). Перший організовувався за сприяння міністерства торгівлі й промисловості приватними підприємцями, другий - за ініціативою агента міністерства торгівлі й промисловості в Тегерані (Shimanovskii, Leites 1913, 26). У 1914 р. уряд Канади організував у Монреалі постійний музей-виставку іноземних товарів. За посередництва РосійськоАнглійської торгової палати тут було відведено місце для зразків сирих товарів і продуктів експорту з Російської імперії (Tovarnye obraztsy, 660).

У 1912 р. друкований орган 3'їдів представників промисловості й торгівлі Півдня Росії (Одеса) «Торгово-промышленный Юг» у кількох номерах опублікував розгорнутий огляд торгових відносин iз Болгарією. Серед бажаних заходів щодо їхнього покращення виділялося і відкриття торгових музеїв у містах Варна та Русе. Також пропонували відкрити такий заклад експонування місцевих товарів в Одесі (G-vich 1912, 28). Отож, успішний приклад роботи європейських експортних музеїв спонукав вітчизняних виробників використовувати цей досвід для пожвавлення власних торгових відносин і розширення ринків збуту. 


\section{Торгово-промислові музеї на українських землях.}

У Російській імперії відкриття приватних торгово-промислових музеїв було справою організаційно складною й вартісною, головним чином відображало рівень розвитку галузі й статус іiі засновників. У кінцевому результаті вітчизняні торгово-промислові музеї, як i європейські, мали сприяти справі експорту, проте їхнє наповнення було іншим, ніж поширених у світі музеїв зразків, та й функції обмежувалися тільки інформаційними й довідковими. Заснування музею, зазвичай, було підсумком тривалого періоду розвитку певної галузі, мало відбивати іiі досягнення та бути наочним свідченням успіхів. Так, за наслідками Всеросійської виставки 1913 р. Київське товариство сільського господарства прийняло рішення заснувати при товаристві сільськогосподарський та промисловий музей (Deiatel'nost' torgovo-promyshlennykh organizatsii, № 20, 58). А на землях вугілля й металу Донецько-Придніпровського району промисловці організували гірничопромисловий музей.

На початку XX ст. однією 3 найвпливовіших представницьких організацій підприємців важкої промисловості на українських землях були 3'їзди гірничопромисловців Півдня Росії (засновані 1874 р.; керівні структури знаходилися в Харкові). На 1914 р. бюджет організації становив понад 8,3 млн руб. (Spravochnaia kniga dlia gornopromyshlennikov, 69). Отож, відкриття промислового музею було для представницького об'єднання скоріше справою статусу, демонстрацією потужностей Південного економічного району.

До Ради 3'їздів гірничопромисловців неодноразово надходили звернення від іноземних музеїв, торгових палат і навчальних закладів про надання зразків вугілля, руд і металів, відомостей 3 історії розвитку та фактичного стану південної гірничої й гірничозаводської промисловості. Приділяючи важливе значення обізнаності широких кіл в Російській імперії та за їі кордонами з промисловим потенціалом Півдня, Рада 3'їздів складала роз'яснення, довідки, проводила презентації. До комерційного музею Белграду було надіслано колекцію мінерального палива й металів, статистичні таблиці, діаграми, карти Донецького басейну, які експонувалися в залі продукції іноземної промисловості на ринку Сербіï (Trudy XXXIV s"ezda gornopromyshlennikov, 81). Виставкова робота З'іздів гірничопромисловців Півдня Росії мала здебільшого стихійний характер, результатом іiі упорядкування стало заснування постійно діючого музею в Харкові.

Ще у 1908 р. Рада З'їздів гірничопромисловців звернулася до вуглепромисловців 3 ідеєю зібрати колекції корисних копалин 
українських земель. Кількарічна підготовча робота увінчалася успіхом, i 1910 р. музей було відкрито для відвідувачів під патронатом технічного відділу Ради 3’їздів гірничопромисловців Півдня Росії (Otchet Soveta S"ezda XXXIV, 7). Технічний персонал зосередився головним чином на графічних і картографічних роботах: виготовленні нових діаграм, контактних відтисків і збільшень; систематизації фотографічних світлин. Працівниками музею були зібрані матеріали 3 житлового питання, шкільної та медичної справи.

Музей розміщувався в п'яти залах (м. Харків, вул. Сумська, 18), де було представлено вогнетривкі, металургійні, кам'яновугільні, антрацитові вироби й колекцію кам'яної солі та руд (залізної, марганцевої, ртутної, свинцевої, срібло- й золотоносної). Окремо було оформлено вітрину рудних багатств Уралу. Окрасою музею стали колекції кам'яного вугілля та антрацитів у формі вишуканих ваз, геологічні мапи, кінематографічні картини рудничної та заводської праці (Trudy XXXV s"ezda gornopromyshlennikov, 28). Витрати на утримання музею кошторисом гірничопромисловців на довоєнний 1913 р. було заплановано в сумі 7500 руб., на 1914 р. - близько 6700 руб., на 1915 р. витрати були суттєво скорочено - до 4694 руб., на 1916 р. заплановано в розмірі 5500 руб. (Trudy XXXVII s"ezda gornopromyshlennikov, 59; Trudy XXXVIII s"ezda gornopromyshlennikov, 58; Trudy XL s"ezda gornopromyshlennikov, 55; Trudy XL s"ezda gornopromyshlennikov, 63).

Щоб показати гірничопромисловий Південь не тільки як виробника, a i як споживача, окреслити широкі торгово-промислові зв'язки у музеї демонстрували експонати фірм-партнерів підприємств Донецького басейну. У 1916 р. тут було виставлено колекцію нафтових продуктів, подаровану «Товариством Бр. Нобель» (Trudy XLI s"ezda gornopromyshlennikov, 263).

Музей надавав послуги довідкового характеру 3 питань покладів корисних копалин Донбасу й Придніпров'я. Загальна кількість відвідувачів гірничопромислового музею на 1913 р. досягла 1189 осіб (Trudy XL s"ezda gornopromyshlennikov, 64). Були серед них і високопосадовці. Так, 6 березня 1915 р. до музею завітав міністр торгівлі й промисловості князь В. М. Шаховський у супроводі директора Гірничого департаменту В. І. Арандаренка для ознайомлення з потужностями південної гірничої промисловості в умовах Першої світової війни. У березні 1917 р. музей відвідала французька торгово-промислова делегація (Frantsuzskaia torgovo-promyshlennaia delegatsiia, 15487).

Під час Першої світової війни частина приміщень музею використовувалася під лазарет, облаштування нових колекцій було 
суттєво ускладнено. Проте звичайна музейна робота не припинялась: альбоми поповнювалися новими світлинами й діаграмами, було замовлено карту Криворізького залізорудного району, йшла підготовка матеріалів для довідника корисних копалин Європейської частини Російської імперії. Проявом воєнного часу стала виставка зразків військового спорядження. У 1917 р. при музеї планувалося облаштувати геологічну бібліотеку (кошторис - 1000 руб.) (Trudy XLI s"ezda gornopromyshlennikov, 265).

Подальші політичні події суттєво змінили не тільки роботу цієї установи, а й увесь поступальний соціально-економічний і суспільнополітичний розвиток українських земель. Імовірно, на початку 20-х рр. $\mathrm{XX}$ ст. колекції гірничопромислового музею стали частиною Харківської промислової виставки Вищої ради народного господарства.

\section{Музей зразків при Російській експортній палаті.}

За зразком західноєвропейських установ, які «надавали справі експорту величезні послуги», при Російській експортній палаті (далі- РЕП) у вересні 1913 р. було відкрито «музей зразків» з комісійним відділом. РЕП розпочала свою роботу в лютому 1911 р., іï головне завдання полягало в теоретичному вивченні та практичному здійсненні експорту. Відкриття музею виявилося нагальною потребою і логічним розширенням роботи РЕП та їі довідкового бюро. Численні запити до бюро та його посередницькі послуги, у ході виконання яких надсилалися зразки товарів, а також часті відвідування самої Палати іноземними торговими представниками, спонукали керівництво РЕП облаштувати спеціальне приміщення для експонування експортних товарів - тобто музей зразків.

Музей не ставив собі непосильної мети зібрати все, що має експортний інтерес. Для реалізації такого завдання знадобилися б колосальні кошти й окреме місце розташування. Його роль була більш скромна і, водночас, більш практична 3 комерційної точки зору - музей мав характер постійної виставки зразків різноманітних сільськогосподарських та промислових товарів. Свою експозицію тут міг мати кожен виробник, який хотів наочним чином рекламувати власну продукцію в столиці для широкої публіки іноземних партнерів. Для цього слід було орендувати площу під свою експозицію: вартість становила від 50 коп. до 3 руб. на місяць за квадратний фут в залежності від терміну оренди (Instruktsiia muzeiu obraztsov, 245; Otchet Rossiyskoi éksportnoi palaty, 305). Організатори висловлювали впевненість, що заснування першого в імперії музею зразків «безперечно буде сприяти спеціальному приїзду іноземних покупців» (пер. 3 рос.) (Muzei obraztsov pri Rossiiskoi éksportnoi palate, 244). Уся інформація щодо 
нових надходжень до музею безкоштовно публікувалася в друкованому органі РЕП - журналі «Русский экспорт» (Instruktsiia muzeiu obraztsov, 245). Згодом було видано каталог музею зразків РЕП російською та англійською мовами (Katalog muzeia obraztsov R.É.P., 200).

На кожен представлений експонат надавалася інформація щодо його якості, цін, умов виробництва й збуту, а також каталоги й прейскуранти фірм-виробників (Otchet Rossiyskoi éksportnoi palaty, 305). У примітці до інструкції роботи комісійного відділу вказувалося, що «для товарів швидкопсувних або громіздких наявність зразків необов'язкова» (пер. з рос.), достатньо було друкованої рекламної продукції або муляжів. До певної міри музей виконував функцію торгового представництва, адже кожна фірма-експонент мала можливість давати оголошення про розміщення тут своїх зразків. Працівники комісійного відділу надавали сприяння у прийомі замовлень і здійсненні торгових угод. Завідування музеєм було покладено на одного з помічників управителя справами РЕП під загальним наглядом останнього (Muzei obraztsov Rossiiskoi éksportnoi palaty, 214). У разі накопичення незатребуваних зразків періодично влаштовувався їхній розпродаж або аукціон (Instruktsiia muzeiu obraztsov, 245).

У музеї зразків експонувалися найрізноманітніші товари (переважно сільськогосподарські та кустарні): таврійська сіль, ташкентське вино, житомирське борошно, семиріченський мед, костромські текстильні вироби і навіть насіння червоної конюшини з Уфимської губернії та мозаїчні смоли з Нижегородської губернії (Otchet Rossiyskoi éksportnoi palaty, 307-308). Від закордонних партнерів були отримані такі зразки: китайське олійне насіння й бавовна, рогові вироби німецького фабриканта, константинопольський бурштин, чеські гудзики, датський картон та ін. (Otchet Rossiyskoi éksportnoi palaty, 308).

Окремо в музеї був спеціальний відділ премійованих пакувань, тобто найновіших на той час удосконалень у пакувальній справі, які були придбані на спеціалізованій виставці у Парижі (пакування для перевезень квітів, ягід, фруктів, вина та ін.) (Otchet Rossiyskoi éksportnoi palaty, 308). Особливої уваги серед експонатів заслуговувала «тара повернення», яка дозволяла виробникам мати суттєву економію у зв'язку з постійним подорожчанням лісу й пакувальних матеріалів. Серед прикладів такої тари зворотної відправки знаходимо розбірні ящики, залізні діжки, які згорталися в трубку й інші пакувальні винаходи.

Крім музейного закладу в Санкт-Петербурзі у 1913 р. РЕП розпочала організацію «торгових подвір'їв», перше з них було відкрито в Софії (Болгарія). За задумом, «подвір'я» мало створити постійний торговий 
музей зразків російських експортних товарів, організувати довідкове бюро $з$ питань російсько-болгарської торгівлі та бібліотеку, проводити виставки, утримувати штат досвідчених комівояжерів для поширення російських товарів, мати кімнати для перебування російських комерсантів та здійснювати інші дії суто практичного характеру (Deiatel'nost' torgovo-promyshlennykh organizatsii, № 12, 55).

На початку 1914 р. Комітет Палати схвально зустрів пропозицію своїх членів А. І. Маркова та К. С. Лейтеса про організацію в Берліні експортного комісійного бюро музею зразків Палати (Deiatel'nost' komiteta Palaty, 114). Планувалося всі торгові контракти здійснювати за посередництва музею зразків РЕП. Та цим планам не судилося бути реалізованими. Так само на стадії відкриття загальмувала ідея створення Російського музею зразків у Лондоні. Хоча РЕП і отримала підтримку цього проекту від генерального консула в Лондоні барона Гейкинга, заклад так і не було відкрито.

Музей зразків РЕП був швидко помічений закордонними партнерами. Від директора торгово-промислового бюро японського міністерства землеробства й торгівлі Мінору Оки було отримано вітального листа, в якому посадовець поспішав висловити найкращі побажання 3 приводу новоствореного музею та впевненість, що його робота «матиме суттєве сприяння зовнішній торгівлі Вашої країни [Російської імперії]» (пер. з рос.) (Interes v Iaponii k muzeiu obraztsov, 219). Разом із привітанням, японські партнери надіслали колекцію зразків товарів Японії, брошуру «Общий обзор торгового музея в Токио» та «Справочную книгу экспорта Японии» i, зі свого боку, запрошували розмістити колекцію зразків експортних товарів у їхньому музеї.

Від Японського Імператорського музею до музею РЕП надійшли такі зразки традиційного японського виробництва: паперові серветки, шовксирець, шовкові тканини, гудзики, віяла, рогожі, зелений та чорний чай, порцеляна, шпалери та ін. (Muzei obraztsov, 311-313).

Таким чином, музей зразків був своєрідною експортною конторою, де кожен її учасник мав можливість мати на головній вулиці країни - Невському проспекті - своє мініатюрне представництво. Сам же Комітет РЕП вважав музей зразків «практичним шляхом активного сприяння експорту вітчизняних продуктів і виробів» (Muzei obraztsov pri Rossiiskoi éksportnoi palate, 244).

\section{Музей зразків Російсько-Американської палати.}

Російсько-Американська торгова палата впродовж 1914 р. теж розпочала організацію музею зразків, але тільки американських партнерів. Стримуючим фактором у цьому процесі була необхідність сплати мита, оскільки в Російській імперії зразки не звільнялися від 
митного обкладення (Otchet o deiatel'nosti Russko-Amerikanskoi torgovoi palaty, 159). Згодом відповідне клопотання Російсько-Американської торгової палати до російського уряду було вирішено позитивно (Iz deiatel'nosti Russko-Amerikanskoi torgovoi palaty, 318).

Окрім зразків, Палата збирала каталоги, рекламні проспекти й прейскуранти американських фірм-виробників та торгово-промислові довідники 3 питань експортно-імпортної політики, аби завжди мати інформацію про умови виконання замовлень, терміни доставки вантажів, порти відправлення, оптові ціни, знижки для агентів, форми оплати і т. п. Уже в квітні 1915 р. бібліотека нараховувала понад 300 екземплярів каталогів і продовжувала безперервно поповнюватися (Doklad o deiatel'nosti, 160). Упродовж наступного року фонд бібліотеки збагатився ще на 3 тис. каталогів, прейскурантів, спеціалізованих американських журналів та іншої літератури. Товарний музей містив такі колекції: вогнестійкі будівельні матеріали, папір для друку, шкіри, канати, шпагати, шовкові стрічки, різноманітні інструменти, металеві вироби, хімічні й фармацевтичні товари, продукти харчування та ін. (Spravka o deiatel'nosti Palaty, 231).

Зважаючи на зміст каталогів, американських виробників цікавила можливість експорту до Російської імперії товарів машинобудівної та автомобільної промисловості. Російські експортери надсилали запити для вивозу до Північно-Американських Сполучених Штатів виробів легкої й харчової промисловості, а також аграрної продукції.

Отож, на початку XX ст. в Російській імперії створюється кілька музеїв зразків, що, однак, не могло відтворити в повному обсязі експортних потужностей виробників i серед усього розмаїття експонатів гідно представити експортно орієнтовані товари українських губерній.

$$
* * *
$$

Швидкий і динамічний час капіталістичної модернізації приніс багато нових явищ і нових усвідомлень здавна відомих установ. Новим стало наповнення й функціональне призначення такого споконвічного супутника розвитку людства як «музей». Наприкінці XIX - на початку XX ст. музейна форма використовується для реалізації суто комерційних завдань: збут та популяризація товарів власного виробництва для іноземних споживачів.

У цей час як за кордоном, так і в Російській імперії формуються торгово-промислові музеї, музеї зразків, експортні склади. Наведені поняття не $\epsilon$ тотожними (хоч часто використовувалися як синоніми): торгово-промислові музеї зазвичай не брали участі в експортних операціях, а експортні склади - тільки цим і займалися; якщо перші - 
представляли регіон чи країну у цілому, то останні - у більшості випадків належали конкретній фірмі. Ще одна форма економічних музеїв - «музеї зразків» - були покликані узгодити два головні завдання «експортної сутності в музейній формі»: і створити образ, експозицію, своєрідне представництво певного виду виробництва чи економіки країни у цілому, і сприяти збуту товарів, здійснювати супровід торгових угод.

У державах розвинутих економік мали місце, головним чином, два види експортних музеїв: музейне представництво в країнах бажаного вивозу; музеї зразків у власній країні для ознайомлення іноземних покупців 3 асортиментом вітчизняного виробництва. Але можлива й інша класифікація торгово-промислових музеїв: 1) експортні (музеї зразків); 2) іміджеві (статусні, інформаційні). Перші були створені головним чином задля вирішення комерційних завдань, другі - загального інформування з успіхами тієї чи тієї галузі, виконання довідкових функцій. Усі види й форми торговопромислових музеїв у своїй сукупності, за оцінками сучасників, сприяли пожвавленню торгових відносин між країнами, дозволили опанувати нові методи популяризації товарів, взаємозбагатили зміст, структуру й форми виробничо-споживчих відносин на світовому ринку.

У експортно орієнтованих діях Російської імперії наприкінці XIX на початку XX ст. зустрічаємо прагнення формувати обидва види музейних представництв («в межах країни», «за межами країни»). Проте процес створення експортних музеїв знаходився тут ще у зародковому стані, наштовхувався на численні організаційні труднощі, жорстку конкуренцію зі світовими торговими лідерами у справі відкриття своїх економічних музеїв у країнах бажаного експорту та, досить часто, через недостатнє усвідомлення підприємницькими колами в Російській імперії необхідності додаткових витрат на організацію музеїв зразків.

Товари з українських земель були мало представлені узагальноімперських експортних музеях не в останню чергу через бажання підприємців укладати прямі угоди без посередників. Економічні музеї створювалися загального торгово-промислового характеру (іміджеві).

Для більшості музеїв експортного спрямування кінця XIX - початку $\mathrm{XX}$ ст. більше підходило б визначення «експортний склад» (таке визначення теж використовувалася) чи «колекція (відділ) зразків». Чому ж «музей»? Відповідь на це питання лежить у площині соціальних і світоглядних змін нового часу: еліта за походженням змінилася на еліту за статками, а отже відбулося переосмислення поняття «культурні надбання». До них були віднесені і економічні цінності, для представлення яких використовувалася традиційна для збереження культурних цінностей форма - музей. 


\section{References / Бібліографія}

Abbo, B. Les Boutiques de Musees: Un Exemple des Relations Entre le Monde Commercial et le Monde Museal. Lyon, 1993.

Deiatel'nost' komiteta Palaty. Russkiy eksport, no. 3, 1914, s. 113-114. (In Russian) Деятельность комитета Палаты. Русский экспорт, № 3, 1914, с. 113-114.

Deiatel'nost' torgovo-promyshlennykh organizatsii. Torgovo-promyshlennyy Yug, no. 12, 1913, s. 52-56. (In Russian)

Деятельность торгово-промышленных организаций. Торговопромышиленный Юг, № 12, 1913, с. 52-56.

Deiatel'nost' torgovo-promyshlennykh organizatsii. Torgovo-promyshlennyy Yug, no. 20, 1913, s. 53-60. (In Russian)

Деятельность торгово-промышленных организаций. Торговопромышиленный Юг, № 20, 1913, с. 53-60.

Doklad o deiatel'nosti Russko-Amerikanskoi torgovoi palaty za ianvar', fevral', mart i aprel' mesiatsy 1915 goda. Vestnik Russko-Amerikanskoy torgovoi palaty, no. 5, 1915, s. 160-174. (In Russian)

Доклад о деятельности Русско-Американской торговой палаты за январь, февраль, март и апрель месяцы 1915 года. Вестник РусскоАмериканской торговой палаты, № 5, 1915, с. 160-174.

Éksportnye soiuzy za granitsei. Russkiy eksport, no. 4, 1914, s. 128-132. (In Russian)

Экспортные союзы за границей. Русский экспорт, № 4, 1914, с. 128-132.

Frantsuzskaia torgovo-promyshlennaia delegatsiia v g. Khar'kove. Gornozavodskoe delo, no. 10, 1917, s. 15484-15487. (In Russian)

Французская торгово-промышленная делегация в г. Харькове: 1917. Горно-заводское дело, № 10, 1917, с. 15484-15487.

G-vich, V. Nashi torgovye snosheniia s Bolgariei. Torgovo-promyshlennyi Iug, no. 4, 1912, s. 17-28. (In Russian)

Г-вич, В. Наши торговые сношения с Болгарией. Торгово-промышленный Юг, № 4, 1912, c. 17-28.

Huber, F. C. Die Ausstellungen und unsere Exportindustrie. Stuttgart, 1886. 
Instruktsiia muzeiu obraztsov i Komissionnomu otdelu muzeia. Russkii eksport, no. 7-8, 1913, s. 245-246. (In Russian)

Инструкция музею образцов и Комиссионному отделу музея. Русский экспорт, № 7-8, 1913, с. 245-246.

Interes v Iaponii k muzeiu obraztsov Rossiiskoi eksportnoi palaty. Russkii eksport, no. 5-6, 1914, s. 219-220. (In Russian)

Интерес в Японии к музею образцов Российской экспортной палаты. Русский экспорт, № 5-6, 1914, с. 219-220.

Iz deiatel'nosti Russko-Amerikanskoi torgovoi palaty. Vestnik RusskoAmerikanskoi torgovoi palaty, no. 9, 1915, s. 315-318. (In Russian)

Из деятельности Русско-Американской торговой палаты. Вестник Русско-Американской торговой палаты, № 9, 1915, с. 315-318.

Katalog muzeia obraztsov R.É.P. Russkii eksport, no. 11, 1915, s. 200. (In Russian) Каталог музея образцов Р.Э.П. Русский экспорт, № 11, 1915, с. 200.

Le Musée Commercial, son but et son organization. Bruxelles, 1883.

Mairesse, F. Aux origines du musée d'entreprise: Musées industriels et commerciaux. Recherches en communication, no. 45, 2018, pp. 7-21.

Muzei obraztsov. Russkii eksport, no. 9-10, 1914, s. 311-314. (In Russian) Музей образцов. Русский экспорт, № 9-10, 1914, с. 311-314.

Muzei obraztsov pri Rossiiskoi éksportnoi palate. Russkii eksport, no. 7-8, 1913, s. 244-245. (In Russian)

Музей образцов при Российской экспортной палате. Русский экспорт, № 7-8, 1913, с. 244-245.

Muzei obraztsov Rossiiskoi éksportnoi palaty. Russkii eksport, no. 11, 1915, s. 213-214. (In Russian)

Музей образцов Российской экспортной палаты. Русский экспорт, № 11, 1915, c. 213-214.

Nadezhdin, K. Rol' i znachenie torgovykh muzeev v dele pod"ema éksporta. Ekonomist Rossii, no. 51-52, 1911, s. 5-7. (In Russian)

Надеждин, К. Роль и значение торговых музеев в деле подъема экспорта. Экономист России, № 51-52, 1911, с. 5-7. 
Otchet Khar'kovskogo birzhevogo komiteta za 1890 god. Khar'kov, 1891. (In Russian)

Отчет Харьковского биржевого комитета за 1890 год. Харьков, 1891.

Otchet o deiatel'nosti Russko-Amerikanskoi torgovoi palaty za 1914 g. Vestnik Russko-Amerikanskoy torgovoy palaty, no. 5, 1915, s. 156-160. (In Russian)

Отчет о деятельности Русско-Американской торговой палаты за 1914 г. Вестник Русско-Американской торговой палаты, № 5, 1915, с. 156-160.

Otchet Rossiyskoi éksportnoi palaty za 1913 god. Sankt-Peterburg, 1914. (In Russian)

Отчет Российской экспортной палаты за 1913 год. Санкт-Петербург, 1914.

Otchet Soveta S"ezda XXXIV S"ezdu gornopromyshlennikov Iuga Rossii za 1908-1909 otchetnyi god. Khar'kov, 1909. (In Russian)

Отчет Совета Съезда ХХХІV Съезду горнопромьиленников Юга России за 1908-1909 отчетный год. Харьков, 1909.

Roshchin, S. Torgovo-promyshlennye muzei Anglii. Ekonomist Rossii, no. 16,1909 , s. 16. (In Russian)

Рощин, С. Торгово-промышленные музеи Англии. Экономист России, № 16,1909 , c. 16.

Russko-Kitayskii torgovo-promyshlennyi muzei. Promyshlennost'i torgovlia, no. 9, 1910, s. 638. (In Russian)

Русско-Китайский торгово-промышленный музей. Промышленность $u$ торговля, № 9, 1910, с. 638.

Shimanovskii, V. Iu., Leites, K. S. Pravitel'stvennye uchrezhdeniia $i$ obshchestvennye organizatsii, obsluzhivaiushchie $v$ Rossii $i$ Germanii voprosy éksporta. Sankt-Peterburg, 1913. (In Russian)

Шимановский, В. Ю., Лейтес, К. С. Правительственные учреждения и общественные организации, обслуживающие в России и Германии вопросы экспорта. Санкт-Петербург, 1913.

Spravka o deiatel'nosti Palaty. Vestnik Russko-Amerikanskoi torgovoi palaty, no. 8, 1916, s. 228-232. (In Russian)

Справка о деятельности Палаты. Вестник Русско-Американской торговой палаты, № 8,1916 , с. 228-232. 
Spravochnaia kniga dlia gornopromyshlennikov Inga Rossii. Khar'kov, 1916. (In Russian)

Справочная книга для горнопромышленников Юга России. Харьков, 1916.

Steffen, G. F. Streifzüge durch Grossbritanien. Stuttgart, 1896.

Tovarnye obraztsy. Promyshlennost' $i$ torgovlia, no. 12, 1914, s. 660. (In Russian)

Товарные образцы. Промышленность и торговля, № 12, 1914, с. 660.

Trudy XXXIV s"ezda gornopromyshlennikov Iuga Rossii (23 noiabria 8 dekabria 1909 g.). T. 1. Khar'kov, 1909. (In Russian)

Труды XXXIV съезда горнопромышленников Юга России (23 ноября 8 декабря 1909 г.). Т. 1. Харьков, 1909.

Trudy XXXV s"ezda gornopromyshlennikov Iuga Rossii (23 noiabria 9 dekabria 1910 g.). T. 2. Khar'kov, 1910. (In Russian)

Труды XXXV съезда горнопромышленников Юга России (23 ноября 9 декабря 1910 г.). Т. 2. Харьков, 1910.

Trudy XXXVII s"ezda gornopromyshlennikov Iuga Rossii (25 noiabria 4 dekabria 1912 g.). T. 1. Khar'kov, 1913. (In Russian)

Труды XXXVII съезда горнопромышленников Юга России (25 ноября 4 декабря 1912 г.). Т. 1. Харьков, 1913.

Trudy XXXVIII s"ezda gornopromyshlennikov Iuga Rossii (27 noiabria 6 dekabria 1913 g.). T. 1. Khar'kov, 1914. (In Russian)

Труды XXXVIII съезда горнопромышленников Юга России (27 ноября 6 декабря 1913 г.). Т. 1. Харьков, 1914.

Trudy XL s"ezda gornopromyshlennikov Iuga Rossii (21-29 noiabria 1915 g.). T. 1. Khar'kov, 1916. (In Russian)

Труды XL съезда горнопромышленников Юга России (21-29 ноября 1915 г.). Т. 1. Харьков, 1916.

Trudy XL s"ezda gornopromyshlennikov Iuga Rossii (21-29 noiabria 1915 g.). T. 2. Khar'kov, 1916. (In Russian)

Труды XL съезда горнопромышленников Юга России (21-29 ноября 1915 г.). Т. 2. Харьков, 1916. 
Trudy XLI s"ezda gornopromyshlennikov Iuga Rossii (24 noiabria 4 dekabria 1916 g.). T. 2. Khar'kov, 1917. (In Russian)

Труды XLI съезда горнопромышленников Юга России (24 ноября 4 декабря 1916 г.). Т. 2. Харьков, 1917.

Ianzhul, I. I. Torgovye muzei, éksportnye soiuzy i sklady tovarnykh obraztsov. Moskva, 1897. (In Russian)

Янжул, И. И. Торговые музеи, экспортные союзы и склады товарных образцов. Москва, 1897.

Shandra Iryna Alexandrovna Doctor in Historical Science, Associate Professor Kharkiv State Academy of Culture Bursatsky Uzviz, 4, 61057, Kharkiv, Ukraine Email: irina_shandra@ukr.net ORCID: 0000-0002-9092-413X

\section{COMMERCE AND INDUSTRY MUSEUMS AS A MEANS OF BOOSTING TRADE: GLOBAL AND NATIONAL EXPERIENCE (LATE 19th AND EARLY 20th CENTURIES)}

In the late 19th and early 20th centuries, to revive exports and boost trade between countries, business circles began founding special institutions - museums of commerce and industry, export museums, or museums of samples. The creation of such institutions, the functional purpose of their main structural components, and their principal activities can be studied using the vast body of current and analytical data from early 20th-century periodicals and documents of business unions and government and business organizations established to aid foreign trade (the Russian Export Chamber in St. Petersburg; Southern Russia mining industry congresses in Kharkiv; Kharkiv Exchange Committee, and others). The article analyzes commerce and industry museums as tools designed to help achieve the economic goals of groups of entrepreneurs and states as a whole. It is emphasized that these institutions contributed to the intensification of trade between countries and promoted the sharing of the latest developments and methods in this sphere (such as those that had to do with concluding and servicing commercial agreements, creating a broad information base and providing reference information, maintaining contacts between producers and consumers, implementing new practices in the packing and shipping of goods, etc.). The article proposes different 
versions of the classification of export-oriented museums - by location (in the country of production, in the country of possible export) or by main purpose (export, brand promotion). Comparative analysis of the activities of Western European export museums and sample museums in the Russian Empire leads the author to conclude that Russia lagged significantly behind in establishing institutional forms for aiding foreign trade; such museums remained rare across the empire and did not adequately represent the available range of export goods.

Keywords: commerce and industry museum, export museum, museum of samples, trade. 